\title{
Analysis of the State of Elementary School Student Population of East Azerbaijan during 2006-2016 and Predictions of Space and Educational Staff Required in this Field
}

\author{
Elham tamjidtash \\ Member of Young Researcher's Club in Islamic Azad University, Bonab, Iran. \\ Email: tamjidtash@yahoo.com \\ Mohammad Ali Mojallal Chooboghloo Phd
}

Assistant professor \& member of the scientific mission Azad university, Bonab, Iran

Email:mojallal.2006@yahoo.com

\section{Doi:10.5901/mjss.2014.v5n16p273}

\begin{abstract}
Evaluation of population structure provides the possibility of predicting and estimating of requirements of human resources. Obviously, it will be impossible predict of future requirements if no exact knowledge of the characteristics of the population. Therefore the present study analyzes the primary student population of East Azerbaijan and predicts its' required space and educational staff in the next five years. The purpose of this research is applied and the type of data gathering in this study is a descriptive - analytical one. The statistical population of this study includes the total student population and expert human resources in East Azerbaijan primary education. Research tools are to refer to the Department of Education of the province and library study by using statistics and necessary information and also study of Statistical Yearbook and census results. Statistical methods of this research are: Population prediction using calculation the survival rate, Johnston formula and the rate's morality and migration of school-age population, predictions of schools enrollment rates in local-scale and estimate of required space and educational staff in the next five years in the next five years according to provincial standards. The results of this study showed that the number of primary school students in the 2016 school years compared to1390-1391 school years will increase by $4 / 63$ percent. And consequently, the need for classrooms, educational spaces, an expert (teacher) and educational staff in the next five years will increase.
\end{abstract}

Keywords: student population, primary school, Population predictions, educational space, educational staff.

\section{Introduction}

The importance of education in general and elementary education in particular cannot be ignored. Certainly, there is an agreement about that a high level of economic development cannot be created in a mostly illiterate population. On the other hand, as one of the individual human rights permanently education is emphasized. Education is mentioned as one of the greatest and most important rights of each individual in the United Nations Charter in 1945(United Nations, 2003: 5-6) and as the basis of other levels, elementary education has an important place between different levels of education, so that elementary education is the education level of democratic in most countries, because essentially it is assumed that elementary education is open on all classes of society. (Garcia Grrydv 1995: A).

According to the findings of the United Nations education has been identified as one of the essential components for human and social development. The right of education has been emphasized in the Universal Declaration of Human Rights and the importance of education has been confirmed based on population and individual progress in most of the major United Nations conferences and meetings. In addition, education has been emphasized in all international conferences on population, the practical programs of international conferences on population and development (1994) accepted quantitative goals related to education and in 1999, major programs were adopted to more practical instructions of the International Conferences on population also as a medium-term objective, the rate of the net enrollment in elementary school was determined at least $90 \%$ for both genders until 2010.

General concept of education is to provide the appropriate factors for unlocking human potential and his evolutionary movement toward the desired goal by a measured program. Certainly it can be said that a program that is designed without regard to the quantitative aspects of education, will not be a measured program. So nowadays recognize the population variables has undeniable and important role in educational planning. Without such knowledge, it 
will be difficult to provide educational programs and predict capabilities and future needs of students.

Today society considers the quantitative expansion of education favorable and takes into account it as the source of progress. So in all of the development programs, people benefit from education is on the top of educational policy and educational planning and policy would be reasonable only if they are based on calculated predictions and estimates it should be noted that knowledge of the characteristics of the student population is very important and necessary for future planning of the educational system.

\section{Theoretical Principles of Research}

The study of the population structure means the study of its combination in other words, in the study of population structure, population distribution considered based on predetermined criterion. Because of several reasons, educational planners study the distribution of population. The main reasons are as follows:

1. The study of population distribution based on age and sex which allows planners to estimate the relative population number needed to teach and it is the starting point of all education policies.

2. The study of population distribution based on classification of economic activities and various occupations which if there is a lack of detailed knowledge of population distribution, it will be impossible to predict manpower needs.

3. The study of geographical distribution of the population which is important from two aspects. First, it affects education expenses and the other it is effective in determining the number and type of schools (Chav, 2010: 2).

Effective factors in quantitative trends of elementary education in general, can be divided into two categories: 1Demographic factors (fertility population, mortality, and immigration and population growth) and 2-Educational coverage factor.

Reproductive is the major determinant of age composition of a population. Age composition of population is determined by past fertility to mortality and these changes affect on the demand for education and the community's ability to meet these demands (stemper 1972:34). In other words, increase in the birth rate is equal to demand for elementary school capacity about 7-15 years later. And if it is rapid increase in fertility it can impose heavy pressure on education (Fougstedt, 1975:47).

The number of seven year old children who must attend school every year is dependent on the level of fertility and birth about the last seven years (Amani, 1998:72). In fact, impact of decreased fertility on enrollment will be delayed essentially, because children do not attend school until six years old (Jones, 1990:75).

In a society where schools do not have sufficient capacity to attract students 5-7 years, sudden and high growth in fertility may be contain a lot of pressure on the capacity of schools, so it causes a dramatic increase in the number of students and in the first stage, leading to an increase in the proportion of students to class and When the total capacity of the school was too it will caused to numerous problems for the educational system and even for the administrative system(Fougstedt, 1975:97).

Mortality status also is an important factor on population trends in education, especially elementary education. The greatest impact of mortality on education lies in children mortality. Reducing infants and children mortality means increasing the required capable population for education. Infant and children mortality trend is an important factor for educational planning (Jones, A 1975:81).In fact, decrease infants and children mortality expands the base of age pyramid and subsequently leads to an increase population in the school-age (Girard, 1975:26).

Probability of survival from birth to seven years is effective in number of enrollments and number of first-year students. For example, if in a country almost all births due to improved health reach to seven years, the number of students enrolled in first-grade class is much more than the country has lagged health (Amani, 1998:72). Status of mortality could even be considered at school-age, although mortality at school-age is generally less than other ages, but there is a considerable risk of death in the case of high mortality, even during this period. Therefore, it should be noted that the promotion of a group of class to a higher rank and class it is not only the result of an effort to learn better and success in exams but the probability of survival from an age to an older age plays an important role in this field( the same source:72).

The effects of immigration on education should be considered as important ones. Immigrations have the strong effects on educational population changes from internal point of view. Most of the immigrations are from village to city or from low-population accumulation to high-population accumulation in which this kind of immigration causes some changes in both areas of educational system (Fougstedt, 1975: 49). The main purpose of the most educational plans is to decrease the unequal amount of city to village in educational system by developing educational facilities in village areas 
(with a high speed in cities. One of its results is the loss of predicted educational plantings' and increasing the number of registration in a fix manner and predicted ways of expenditures by the high number of immigration to cities (Jones, 1990: 57). It is expected in the cities that the expensiveness in educational expenditures created in which cause to the great pressure on budgeting, developing schools in cities, increasing of classes' capacities that cause decreasing in the quality of education (Golshani Fumani, 2001, 187).

International immigrations had a little effect on educational process because governments control foreign immigrations completely. Also most of foreign immigrants are those who are in a suitable school age (especially elementary levels). The important effect of international immigration is when it takes place in a whole and abundant manner; it also will affect educational ways in the origin and destination country. Elementary education is one of the aspects which reflect the problems of international circumstances quickly.

It can be said that population growth is one of the three main factors of demography (immigrations, death and birth) in which affects the different aspects of education like educational demand, searching for educational goals, educational expenditures, educational services and.... When educational purposes is emphasized by taking the population into consideration like searching for elementary education or the number of percent iterance to the first grade, or when these purposes are considered by taking the number of population proper for education and learning-teaching process into consideration (like increasing of $30 \%$ to $60 \%$ in the number of passed students from fourth grade to fifth grade). All to all are as reasons for the number of needed age for the school population and this growth of population can be considered as a main factor for getting the purpose of public education (Jones, 1990:30). The growth of the needed age for school population is the main cause of getting the educational purposes in which it is the cause of the population growth especially when the educational coverage is completed. Studies have shown that when the amount of expenditures is recognized, population growth can be enhancing factor of expenditures in order to reach the recognized educational purposes. In fact the growth of population cause to increasing of educational expenditures because the number of new comers is increased so the need for investment can be more felt.

Another important factor which has a direct effect on demographics educational process and is considering as a non-demographics factor, is registration coverage. When only a few amounts of children attend in school, population problem will be considered as a second importance. It can be understood that the effect of population growth is limited on the increasing of students through the effects of strong increasing of the registration (Jones, 1975: 70). This factor has a basic effect on elementary education because having general elementary education is one of the educational goals in most countries (especially on developed countries which do not get to such a goal).

It is clear that by increasing the registration coverage, its effects will be decreased in which when registration coverage is completed, this factor will play as a neutral one. In other word, by literacy contributions in all age levels, registration coverage is completed and the number of illiterate person will be decreased. So, when illiteracy is finished in a country (especially in elementary level), the growth of literate person from one statistics to another will be equal through the growth of the whole needed age for training population ( Amani, 2001: 106).

So two mentioned factors such as demographics factors (birth, death and immigration) and coverage level for school have strong effects on elementary educational needs and facilities. Quality factors directly and indirectly from these two factors has also strong effects. These factors are classroom standards, decrease number of students in class and school, increased use of new technologies in which are determined by planners.

\section{Research Background}

Among all researches about features of students population and its predictions in Iran the following can be mentioned: Zebardast's research( 1996) under the title of "Examining the Kurdistan's students growth and educational staff in last 5 years in order to estimate needed manpower for elementary, guidance and secondary schools for the next 5 years" tries to examine and analyze Kurdistan's educational functions from the students growth and educational staff and predicted the number of elementary, guidance and secondary students for the next 5 years except their levels and majors. Be computed the student's population process, progress and falling rates except school dropout or passing for different periods. He uses the compound growth method and regression method and relative survival rate and also uses unique method and the ratio of student to teacher index in order to predict and determine professional manpower index (needed teachers).

Mirzaie \& Zarghamie's research( 2010) under the title of "Elementary educations demographics changes of country during 1971-2006", tries to examine the elementary students population changes in the country and concluded that in a recent decades, elementary education has a significant demographics changes in which theses population had been increased up to the early decades of 1991 but after that it started to decrease and these changes cause to other changes 
in the number of staffs and teachers and institutes and classes in this level (elementary level). All of these presented in the demographics indexes of elementary education in related years. These indexes like student to teacher ratio, students' accumulation in class and institute and also capita expenses for student are improved in 1971 but they lose the needed standards in 1981. Again they started to improve from 1991. Factors of these changes mostly are countries' population changes and educational coverage in which increasing in registration coverage is one of the effective factors up to 1986 in cities and 1996 in villages.

Zarghami (2010), has examined students' evolutions in 2209-2010 school years. And results of his statistics about educational factors show that Iran's education has finished its population growth period and remarkable increase of student population from the early of 1981 . He stated that nearly $17 / 68 \%$ from the total population of country has been student population in 2009-2010 and from the total student population; nearly $42 / 15 \%$ of student has studied in elementary levels.

With regard to the importance of the mentioned subject, the present study was done in order to estimate the primary school students' population of East Azerbaijan in the next 5 years so that to facilitate the work of educational planners for manpower planning and designing of the future educational programs for primary school.

\section{Research Questions}

1. How and to what extent the evaluation of East Azerbaijan student population in elementary school has been over the 5 last years?

2. How East Azerbaijan primary school student population will be over the next 5 years?

3. To what extent Educational spaces needed for Eastern Azerbaijan primary School students will be to the academic year 2015-2016?

4. How much will be the required number of teaching staff (teachers) for Azerbaijan primary school students to academic year 2015-2016?

\section{Methodology}

The purpose of this research is applied one and its data collection method is descriptive - analytical. The statistical population of this study included East Azerbaijan total student population and manpower of primary education. Researches instruments include refer to the State General Department of Education and library study by suing of needed information and data and also to study statistical yearbooks and census results. Research statistical methods are as follows:

Population prediction by using of calculating of survival rate in a particular age, Johnston formula, the mortality rate and immigration of individuals needed to teaching, prediction of school enrollment rate locally and estimate of state required space and teaching staff in the next 5 years, according to provincial standards. During this research, researcher has predicted student population of the course (through calculating of survival rate in a particular age, Johnston formula, the mortality rate and immigration of individuals needed to teaching) in the next 5 years after the study of state elementary school population growth in the last 5 years and he/she has predicted the required space and the teaching staff to students after estimation of enrollment rate and the number of students in the $96-95$ school year. The survival rate is obtained by subtracting the total population of a particular age group with a population of the same age group who has died one year of age divided by the total population of the age group.

Table 1. Ratio of student to teacher in education courses according to the provincial standards

\begin{tabular}{|c|c|}
\hline Educational courses & Ratio of student to teacher according to the provincial standards \\
\hline Elementary & 17.65 \\
\hline Guidance & 15.17 \\
\hline Secondary & 16.71 \\
\hline
\end{tabular}

Source: Derived from provincial standard of country development document. 
Table 2. Required educational, training and welfare spaces standards in elementary levels

\begin{tabular}{|c|l|c|}
\hline Row & \multicolumn{1}{|c|}{ required educational, training and welfare spaces standards } & scale \\
\hline 1 & theoretical studies classes & $2 \mathrm{~m}$ \\
\hline 2 & empirical studies classes(Laboratory) & $4.5 \mathrm{~m}$ \\
\hline 3 & art classes (playground) & $4.5 \mathrm{~m}$ \\
\hline 4 & library & $4.18 \mathrm{~m}$ \\
\hline 5 & educational activities room & $2.57 \mathrm{~m}$ \\
\hline 6 & gymnasium & $1.6 \mathrm{~m}$ \\
\hline 7 & green space, gardens and tree planting & $3.3 \mathrm{~m}$ \\
\hline
\end{tabular}

Source: Derived from publication of management and planning organization, no. 232.

Table 3. The ratio of students to classes during the educational courses according to the provincial standards

\begin{tabular}{|c|c|}
\hline educational courses & The ratio of students to classes \\
\hline elementary & 20.37 \\
\hline guidance & 26.76 \\
\hline secondary & 21.12 \\
\hline
\end{tabular}

Source: Derived from provincial document of education in fourth development plan

It should be explained that application of the provincial standards in estimating the required space and teaching staff in the 2015-2016 school year is so that educational spaces and schools facilities and also educational staff which should be provided per student, has been taken and has been considered the proportion of each student in the 2015-2016 school year.

V Johnston Model:

Variables of this model are as follow:

$\mathrm{T}=$ predicted year

$E^{g}=$ the number of students in class $\mathrm{g}$

$\mathrm{R}^{\mathrm{g}}=$ the rate or proportion of school-age in group a

$\mathrm{I}=$ net amount transferred it means the number of students who transferred from other units to the class $\mathrm{g}$

\section{Research Findings}

The following information is the result of the research questions which listed in the below tables.

1- How and to what extent the evolutions in East Azerbaijan elementary school student population have been during the past 5 years?

Table 4. The number of East Azerbaijan elementary school students in the last 5 years

\begin{tabular}{|c|c|}
\hline school year & East Azerbaijan elementary school students \\
\hline $2008-2009$ & 269349 \\
\hline $2009-2010$ & 269521 \\
\hline $2010-2011$ & 269743 \\
\hline $2011-2012$ & 273849 \\
\hline $2012-2013$ & 329587 \\
\hline
\end{tabular}

Source: Derived from country's statistical yearbook and East Azerbaijan education statistic.

According to table 4 it is clear that the growth of East Azerbaijan elementary school students' population has been low in recent years and from 2007-2008 to 2010-2011 school years hasn't had much increase. But in 2012-2013 school years the increase has been significant than in previous years and this may be due to adding of six primary bases in the 20122013school years. 
2- How much the East Azerbaijan elementary school student population will be in the next 5 years?

To answer this question first it is necessary to estimate the elementary students population at different bases separately and then it is calculated the total elementary students population in the next 5 years.

Table 5. The estimation of population of East Azarbaijan first grade students in the 95-96 school years

\begin{tabular}{|c|c|c|}
\hline \multicolumn{3}{|c|}{ First grade student population in 2016-2017 school year } \\
\hline province birthdays in 2010 & Rate of survival to one year old & population in 2016 \\
\hline 67734 & 0.896 & 60689 \\
\hline
\end{tabular}

Source: derived from statistical yearbook of East Azerbaijan general administration of registration.

According to table 5 among 67734 children born in2010 years only 0/896 \% of them have survived to age of one. Therefore, it is expected that among the children in this age group, only 60,698 people are attend school in the 20162017 school year.

Table 6. The estimated population of the second grade students of East Azarbaijan in 95-96 school years

\begin{tabular}{|c|c|c|}
\hline \multicolumn{3}{|c|}{ second grade student population in 2016-2017 school year } \\
\hline province birthdays in 2009 & Rate of survival to one year old & population in 2016 \\
\hline 67683 & $90 / 68$ & 61374 \\
\hline
\end{tabular}

Source: derived from statistical yearbook of East Azerbaijan general administration of registration.

According to table 6 among 67683 children born in2009 years only $90 / 68 \%$ of them have survived to age of one. Therefore, it is expected that among the children in this age group, only 61374 people are attend school in the 2016-2017 school year.

Table 7. The estimated population of the third grade students of East Azarbaijan in 2016-2017 school years

\begin{tabular}{|c|c|c|}
\hline \multicolumn{3}{|c|}{ third grade student population in 2016-2017 school year } \\
\hline province birthdays in 2008 & Rate of survival to one year old & population in 2016 \\
\hline 64752 & $89 / 03$ & 57698 \\
\hline
\end{tabular}

Source: Derived from statistical yearbook of East Azerbaijan general administration of registration.

According to table 7 among 64752 children born in 2008 only $89 / 03 \%$ of them have survived to age of one. Therefore, it is expected that among the children in this age group, only 57698 people are attend school in the 2016-2017 school year.

Table 8. The estimated population of the fourth grade students of East Azarbaijan in 2016-2017 school years

\begin{tabular}{|c|c|c|}
\hline \multicolumn{3}{|c|}{ fourth grade student population in 2016-2017 school year } \\
\hline province birthdays in 2007 & Rate of survival to one year old & population in 2016 \\
\hline 63156 & $90 / 42$ & 57101 \\
\hline
\end{tabular}

Source: derived from statistical yearbook of East Azerbaijan general administration of registration

According to table 8 among 63156 children born in2007 only 90/42\% of them have survived to age of one. Therefore, it is expected that among the children in this age group, only 57101 people are attend school in the 2016-2017 school year. 
Table 9. The estimated population of the fifth grade students of East Azarbaijan in 95-96 school years

\begin{tabular}{|c|c|c|}
\hline \multicolumn{3}{|c|}{ fifth grade student population in 2016-2017 school year } \\
\hline province birthdays in 2006 & Rate of survival to one year old & population in 2016 \\
\hline 62689 & $90 / 43$ & 56682 \\
\hline
\end{tabular}

Source: derived from statistical yearbook of East Azerbaijan general administration of registration

According to table 9among 62689 children born in2006 only $90 / 43 \%$ of them have survived to age of one. Therefore, it is expected that among the children in this age group, only 56682 people are attend school in the 2016-2017 school year.

Table 10. The estimated population of the sixth grade students of East Azarbaijan in 2016-2017 school years

$$
\text { sixth grade student population in 2016-2017 school year }
$$

\begin{tabular}{|c|c|c|}
\hline $\begin{array}{c}\text { Pass rate of first-grade } \\
\begin{array}{c}\text { age group in 2011-2012 } \\
\text { school years }\end{array}\end{array}$ & $\begin{array}{c}\text { the number of second grade elementary school } \\
\text { students who will study at sixth base in 2016-2017 } \\
\text { school years }\end{array}$ & $\begin{array}{c}\text { failed third grade of elementary in last year and } \\
\text { descendants of education in the 2012-2013 school } \\
\text { years enrolled in second grade }\end{array}$ \\
\hline $99 / 98$ & 55603 & 23 \\
\hline \multicolumn{2}{|c|}{ total of sixth elementary school students 55626 } \\
\hline
\end{tabular}

Table 11. East Azerbaijan estimated population of the elementary school students in 2016-2017 school years

\begin{tabular}{|c|c|}
\hline grade & population \\
\hline first grade & 60698 \\
\hline second grade & 55626 \\
\hline third grade & 57698 \\
\hline fourth grade & 57101 \\
\hline fifth grade & 56682 \\
\hline sixth grade & 57037 \\
\hline \multicolumn{2}{|c|}{ total : 344833} \\
\hline
\end{tabular}

To answer the second question it should be said that according to table 11 it is expected that around 344833 students at first to sixth grade in elementary level are studying in the 2016-2017 school year.

Table 12. the leaving and imported immigrants into the province during 1996-2006

\begin{tabular}{|c|c|c|c|c|c|c|c|c|}
\hline \multirow{2}{*}{$\begin{array}{l}\text { Province } \\
\text { name }\end{array}$} & \multicolumn{2}{|c|}{$\begin{array}{l}\text { the entered } \\
\text { immigrants }\end{array}$} & \multicolumn{2}{|c|}{ the leaving immigrants } & \multicolumn{3}{|c|}{$\begin{array}{l}\text { the net ratio of migration to } \\
\text { province population (percent) }\end{array}$} & \multirow[t]{2}{*}{ net migration } \\
\hline & number & percentage & number & percentage & & & & \\
\hline \multicolumn{2}{|c|}{ whole of country } & 4774046 & 100 & \multicolumn{2}{|c|}{4774046} & 100 & 0 & 0 \\
\hline \multicolumn{2}{|c|}{ East Azerbaijan } & 158424 & $3 / 32$ & \multicolumn{2}{|c|}{302157} & $6 / 33$ & $-3 / 99$ & -143733 \\
\hline
\end{tabular}

Source: Derived from Ali Ardehaee \& Ali Hosseini's article by the title of Iran's internal immigrations process except province during 1996-2006.

Table 13. origin and target of immigrants according to the latest immigration between 2006-2011

\begin{tabular}{|c|c|c|}
\hline \multirow{2}{*}{ origin of immigration } & \multicolumn{2}{|c|}{ target of immigration } \\
\cline { 2 - 3 } & \multicolumn{2}{|c|}{ city village } \\
\hline city & 3259040 & 755546 \\
\hline village & 655251 & 36870 \\
\hline abroad & 78789 & 23730 \\
\hline not declared & 309006 & 84596 \\
\hline
\end{tabular}

Source: derived from the results of the general census of population and housing in 2011. 
Between 1996 and 2006 a total of 4,774,041 people have been replaced in the provinces of which1438406 people have arrived in Tehran and are living there. After Tehran, most of immigrants respectively have been those who entered Khorasan Razavi with 305305 people and Isfahan with 299943 people and Kohkiluyeh Boyer Ahmad, with 28,647 people has had the lowest number of immigrants. The highest number of total immigrants to Tehran has been from Eastern Azerbaijan because 172,629 people have migrated from the mentioned province to Tehran during 10 years from 19962006 which constitute $12 \%$ of total immigrants who arrived in Tehran. Also this study shows that majority of the migrated people of East Azerbaijan have migrated to Tehran so that a total of 302,157 people during the 10 years which have left his residence in East Azerbaijan $57.31 \%$ to Tehran and the rest (42.87\%) have migrated to the other 29 province (Ardhaee \& Rad, 2009).

Among these provinces, Tehran with 615,027 people has had the highest rate of net migration and Qazvin with 1824 people the lowest net migration while it is negative the net migration rate in the other 18 province. Eastern Azerbaijan has been one of the seven provinces which have sent immigrants to different parts of country more than other provinces so that its digit has been about 143733 people (Ardhaee \& Rad, 2009).

In terms of gender and age groups, the study of immigrants shows that the number of immigrants has increased in both sexes. The number of immigrants in the 1996-2006 in the 5-9 and 10-14 age groups decreased compared to the previous period and it has increased after the 15-19 years age groups and the highest increase especially has been in boys and men in the 20-24 and 25-29 year age groups (the same source, p.6). Therefore it can be said that likely the factor of migration has not significant impact on the population of 6-12 years of East Azerbaijan in the next five years so it is not involved in the estimation of student population.

3- How much will be the required educational spaces of East Azerbaijan elementary school students in year 95$96 ?$

Table 14. the total estimated of the required educational, training and welfare spaces of East Azerbaijan elementary schools according to modern standards in 2016

\begin{tabular}{|c|l|c|}
\hline Row & required educational, training and welfare spaces standards & scale (per student) \\
\hline 1 & theoretical studies classes & $686666 \mathrm{~m}$ \\
\hline 2 & empirical studies classes(Laboratory) & $1551748 / 5 \mathrm{~m}$ \\
\hline 3 & art classes (playground) & $1551748 / 5 \mathrm{~m}$ \\
\hline 4 & library & $1441401 / 9 \mathrm{~m}$ \\
\hline 5 & educational activities room & $886220 / 81 \mathrm{~m}$ \\
\hline 6 & gymnasium & $551732 / 8 \mathrm{~m}$ \\
\hline 7 & green space, gardens and tree planting & $1137948 / 9 \mathrm{~m}$ \\
\hline
\end{tabular}

Table 15. Prediction of the required educational spaces of East Azerbaijan elementary schools in 2016-2017

\begin{tabular}{|c|c|}
\hline $\begin{array}{c}\text { capitation standard of the required educational spaces in } \\
\text { elementary level(based on sqm) }\end{array}$ & $\begin{array}{c}\text { the total number of East Azerbaijan elementary schools } \\
\text { students in 2016-2017 school year }\end{array}$ \\
\hline $3 / 51$ & 344833 \\
\hline
\end{tabular}

Source: estimated according to provincial standards extracted country's development program

According to table 15 East Azerbaijan educational space should be increase to the amount of the predicted student population in the future years so that it can satisfy the students' needs to 1210363/8 Sqm in 2016-2017 school year.

4- How many would be the number of the required teaching staff (teachers) of East Azerbaijan elementary schools students in 2016-2017 school years?

Table 16. Prediction of the number of teachers needed in East Azerbaijan elementary level in 2016-2017 school years with regard to predicted student population

sixth grade student population in 2016-2017 school year

\begin{tabular}{|c|c|c|c|}
\hline \multicolumn{3}{|c|}{ sixth grade student population in 2016-2017 school year } \\
\hline $\begin{array}{c}\text { number of students in } \\
2016-2017 \text { school years }\end{array}$ & $\begin{array}{c}\text { student to teacher ratio } \\
\text { according to provincial standard }\end{array}$ & $\begin{array}{c}\text { number of teachers needed in province } \\
\text { elementary level in 95-96 school year }\end{array}$ & $\begin{array}{c}\text { number of the existing teachers } \\
\text { in 2012-2013 school years }\end{array}$ \\
\hline 344833 & $17 / 65$ & 19863 & 14087 \\
\hline
\end{tabular}


According to table 16 it should be noted that if province education wants to make comply student to teacher ratio with provincial standard, all qualified elementary school teachers should be accordance with the predicted number of teachers required in the above table so that the lack of 5785 qualified teachers be resolved.

Table 17. Comparison of current elementary school students with the number of students in years 2016-2017

\begin{tabular}{|c|c|}
\hline number of elementary school students in 2012-2013 school years & number of students in 2016-2017 school years \\
\hline 329587 & 350581 \\
\hline \multicolumn{2}{|c|}{ rate of population increases 4/63\% } \\
\hline
\end{tabular}

\section{Conclusion}

According to the data resulting from research, in comparison with 2012-2013 school years the number of East Azerbaijan elementary school students will be increased by 4/63 percent in 2016-2017 school years and therefore required number of classrooms, teachers, educational areas and office personnel which is needed at this level will increase in the next 5 years so It is necessary that the provincial education to design its future plans in order to overcome deficiencies and satisfy the future needs so that increasing student population in the future, doesn't lead to the low quality of education and lack of educational spaces in cities and villages doesn't lead to loss of equal educational opportunity.

Capita for elementary school students also schools current and construction budgets should be in accordance with increasing of student population in the future years to province elementary education doesn't face with crisis and lack of quality. Meanwhile it should be noted that the province elementary schools should be expanded accordance with the mentioned standards in table and organize their spaces including educational, administrative, cultural services and recreational spaces according to the codified standards listed in the below table.

\section{Areas of Primary Education According to the Regulations, Technical Standards and Engineering}

\begin{tabular}{|c|c|c|c|c|c|c|c|}
\hline Number of classes & Type of space & Office of the Director & Office of the Assistant & Teachers Room & Finance & Tota & Capitation \\
\hline \multirow{2}{*}{3} & Number & 1 & --- & 1 & 1 & 3 & \multirow{2}{*}{$0 / 37$} \\
\hline & space & 15 & ---- & 15 & 15 & 45 & \\
\hline \multirow{2}{*}{6} & Number & 1 & 1 & 1 & 1 & 4 & \multirow{2}{*}{$0 / 25$} \\
\hline & space & 15 & 15 & 15 & 15 & 60 & \\
\hline \multirow{2}{*}{9} & Number & 1 & 1 & 2 & 1 & 5 & \multirow{2}{*}{$0 / 20$} \\
\hline & space & 15 & 15 & 30 & 15 & 75 & \\
\hline \multirow{2}{*}{12} & Number & 1 & 1 & 2 & 1 & 5 & \multirow{2}{*}{$0 / 16$} \\
\hline & space & 15 & 15 & 30 & 18 & 78 & \\
\hline \multirow{2}{*}{15} & Number & 1 & 1 & 3 & 1 & 6 & \multirow{2}{*}{$0 / 13$} \\
\hline & space & 18 & 15 & 45 & 18 & 81 & \\
\hline \multirow{2}{*}{18} & Number & 1 & 1 & 3 & 1 & 6 & \multirow{2}{*}{$0 / 13$} \\
\hline & space & 18 & 15 & 45 & 22 & 100 & \\
\hline \multirow{2}{*}{21} & Number & 1 & 1 & 4 & 1 & 7 & \multirow{2}{*}{$0 / 14$} \\
\hline & space & 22 & 18 & 60 & 22 & 122 & \\
\hline
\end{tabular}

\section{References}

Abbasi Shavazi, Mohammad Jalal, 2001, Convergance of Fertility Behavior in Iran; The Age Pattern of Fertility in Country's Provinces in 1972 and 1996, Social Science Letter, no. 18, pp. 201-231.

Amani, Mahdi, 2001, "General Demographics of Iran", Tehran, Samt Publication.

Amani, Mahdi, 2005, "Principles of Demographics", $6^{\text {th }}$ edition, Tehran, Samt Publication.

Amjad Zebardast, Mohammad,1996, "The Study of Kurdistan Students Growth \& Province Educational Staff in order to Evaluation of Manpower Needed for Elementary, Guidance and Secondary Schools in the next 5 years, M.A.dessertation, Educational Sciences,Allameh Tabatabaie

Azizzadeh, Hadi, 1993, Thought about Future Evolutions of Iran's Education, set of articles of Sociology \& Development Seminars, Tehran, Samt Publication.

Bogue, Donald; Principles of Demography, Wiley, New York, 1969, P 1-2.

Barro, R. J. and Lee, J. W (1993), International Comparisons of Educational Attainment, Journal of Monetary Economics, No 32: 363394. 
Barro, R. J., Lee J. (2000) International Data on Education Attainment: Updates and Implications. CID Working Paper, No. 42. Cambridge, Harvard University

Biro, Allen,1987, Social Sciences Dictionary, translated by Bager Saroukhani, Tehran, Keyhan Publication, p.86.

Bazargan, Abbas, Sarmad, Zohreh \& Hejazi, Elahe, 2011, Research Methods in Behavioral sciences, 21st edition, Tehran, Agah Publication.

Chav, Tangok, 2010, Demographics in Educational Planning, 1st, edition, translated by Mohammad Reza Keramati \& Mahdi Vafaiezadeh, Tehran, Tehran University Publication.

Christopher, Wilson (1985). The Dictionary of Demography, Paris, publishing company in France, First Edition, p: 968.

David,M\&Barkhof,s(1999).IT in social sciences(Review), The sociological Review,No 47,3,pp 634-637.

Education Statistics, 2009-2010, school years, East Azerbaijan Statistical, Planning and Budget Office.

Emad zadeh, Mostafa,2009, Education Economy,28th Edition,Tehran,Jahade Daneshgahi Publication of Isfahan.

Ettelaat Daily, 2012, Fluctuations of the Population GrowthRate in Cities and Villages in Urban \& Rural Areas, 1 August, no. 25734 , p.4.

Fougstedt, G. (1975), The Effect of demography factors on the demand for education in view of manpower requirements, in Muhsam, $\mathrm{H}$. Education and Population: Mutual impacts, International Union for the Scientific Study of Population, Dolhain, Belgium, Ordina Publication, pp. 43-58.

Fuzat,Yahya,2008,Educational Planing Principles,20th edition,Tehran, Virayesh Publication.

Garsiagorido,Hoze Louise,1995,Elementary Education in the Early of 21 ${ }^{\text {st }}$ Century, Translated by Noruzali Mahdi pur, Tehran,Amir Kabir Publication.

Gasemi Ardehai,Ali \& Hosseyni Rad, Ali,2009,Iran's Internal Immigrations Processes Except Province,during 1996-2006,population Journal, No.66165.

Gasemian, Saieed,1996,Education in Iran and World during 1980-1993, Budjet and Planing Journal, No.11,Tehran,Budjet Organization,PP.43-56.

Gidnez,Antony,1998,Sociology, Translated by Manuchehr Saburi, Tehran,Nashre Ney Publication

Girard, A. (1975), the Effect of demographic variables on education, in Muhsam, H. Education and Population: Mutual impacts, International Union for the Scientific Study of Population, Dolhain, Belgium, Ordina Publication, pp. 25-42.

Golshaniye Foomani,Mohammad Rasul, 2001,Sociology of Education,2nd Edition, Tehran,Agah Publication.

Iran's Statistics Center,2006-2011,General Statistics of Population And Housing, Tehran,Iran's Statistics Center.

Jin,I.,Cortazzi, M(1998).Dimensions of Dialogue:Large Classes in China. International Journal of Educational Research.29,4,pp739-758.

Johnson,D.W\& Johnson,R.T(1992). what to say to advocates for the gifted.Educational leraders,No50(2),pp44-47.

Jones, G. (1975a), Educational planning and population growth, in W. Robinson, Population and development planning, Population Council, New York, pp. 69-93.

Jones, G. (1975b), Population growth and educational planning in Developing Nations, A Population Council Book, Irvington Publishers Inc, New York.

Jones, G. (1990), Population dynamics and educational and health planning, Training in population, human resources and development planning, International Labor Office.

Hosseini, Hatam, 2005, Demographics Principled, Hamedan, Bo-Ali University Publication, 1st edition p.182.

Kalantary, Samad, 1999,Demographics Principles, Isfahan,Mani Publication,p.5.

Kazemipur, Shahla,2004,Demographics Principles,2nd Edition,Tehran,Asia and Pacific Population studies Center,P.109.

Kuller ,R.,Lindsten, C.(1992). Health and behavior of children classrooms with and without windows.Journal of Environmental psychology. 12, 305-317.

Lucas,David \& Mir,Pavel,2005,Brief Review on Populational studies, Translated by Hoseyn Mahmudian,Tehran,Tehran University Publication,2nd Edition,p.182.

Mashayekh,Farideh,2003,The Process of Educational Planing,13 th Edition,Tehran,Madreseh Publication.

Mashayekh,Farideh,2000, New Views on Educational Planing,1st Edition,Tehran, Samt Publication.

Mirzaie, M. (2004), Swing in fertility limitation in Iran, Journal of Social Scince [Nameh-ye Olum-e Ejtemai], No. 22, Tehran, University of Tehran, pp. 1-15.

Mirzaiee,Mohammad,2006, Discussion on Applied Demographics,Tehran,Tehran University Publication, $4^{\text {th }}$ Edition, P.97.

Mirzaiee,Mohammad,2002,Population And Permanent Development, 5th Edition, Tehran, Bashari Publication, p.p.69-83.

Mirzaiee,Mohammad, 1994, Population Studies of Iran's Development,Jamiat Journal, 10th Edition, Tehran, National Organization for Civil Registration, p.p.1-20.

Parkash N.,(2005). The language of Design,NCEF.

Pressat, Roland; The Dictionary of demography, Edited by Christopher Wilson, London, publishing by oxford, 1985. P 54.

Rong, Denis, 1970, Society \& Population, Shiraz, Shiraz University, p.4.

Rivkin M.,(2003).the schoolyard habitat early childhood.education journal, vol.25, No.1.pp 61-66.

Seals,j.R.(1991).Recommendation of standards for educational space for public school facilities.Doctoral Dissertation,Texas university.printed by digital xeroyra phic processon acid free paper.

Shojaie, Alireza, 2004, Educational Spaces,Rules \& Standards, $2^{\text {nd }}$ edition, Tehran, Simay-e Danesh Publication.

Stamper. B. M. (1972), Population and planning in Developing Nations: A Review of sixty development plans for the 1970s, Copy by The Population Council.

Stover, John \& Kermayer, Sharon, 2005, "Population Prediction Software", $4^{\text {th }}$ version, translated by Hatam Hosseini, Tehran: Asia \& 
Pacific Population Studies Center, $1^{\text {st }}$ edition, p.11.

Tagavi, Nematollah, 2008, Demographics Principles, Tabriz, Jamehpazhouh, p.8.

Tamanna, Saeed, 2010, Demographics Principles, Tehran, Peyam Noor University Publication, $6^{\text {th }}$ edition, p.15.

Taylor A., kuo F., sullivan W., (2001).Views of nature and self discipline: evidence from inner city children, journal of environmental psychology.

Thinley,J(1986).primary school buildings standards, norms and design. Unesco department of education.

United Nations (2003), Population, Education and Development: The Concise Report, Department of Economic and Social Affairs Population Division, New York.

Wilson, Christopher; The Dictionary of Demography, Paris publishing company, 1985, First Edition, P:185.

World Bank(2003),World Development Indicators[CD_ROM].Washington D.C:World Bank.

Zanjani, Habibollah, 2002, Evolution in Iran's Population, $5^{\text {th }}$ adition, Tehran, Bashari Publication, pp.41-67.

Zarghami, Hossein \& Mirzaie, Mohammad,2010, Country's Demographics Devolepments in Elementary Education in 1971-2006, Iran's Official Statistics Journal, 21 year, no. 2, Tehran, Iran's Statistics Center, pp. 181-211. 